\title{
Russia's Gas Price Discount for Bulgaria: The Problem of Imperial Economic Projects
}

\section{DMITRY SHLAPENTOKH}

\author{
Indiana University South Bend, United States \\ ORCID No: 0000-0002-4946-0572
}

\begin{abstract}
For a long time Moscow regarded gas line as the source of increasing revenue and the way to project its global influence. Moscow also believed that gas would be always cheaper than LNG and market for gas is bottomless. Nord Stream II and TurkStream have played a crucial role in the setup of the system. However, we see that some problems have emerged recently. There is a clear decline in the prices and interests in Russian gas. It is due to the economic crisis as well as cheap LNG and alternative gas lines. For this very reason, small states like Bulgaria became more assertive towards Russia and compel Moscow to make considerable concessions.
\end{abstract}

Keywords: Bulgaria, Russia, Energy, Natural Gas, Pipelines, TurkStream 
$\mathbf{R}$ ussia’s energy/gas policy in general and the Kremlin's energy/gas policy in the Balkans in particular have been of interest to observers for a long time. Many of them regard Moscow's policy to be informed not just by economic but also by geopolitical interests. Ten years ago, Janusz Bugajski made this clear: "South Stream is also intended to split the EU and prevent the construction of an all-European energy network linking Central Asia, the Caucasus, and Europe that would be independent of Russia's control."

In recent years, several books on the subject, including Bulgaria's role in it, have been published. ${ }^{2}$ The major problem with these books, like that of all books written on current events, is that trends change rapidly. Thus, the situation on the ground must be updated constantly. Until recently, Moscow's plans to bypass Ukraine and become the major supplier of gas to Europe from both the south and east appeared to be an unquestioned success. These plans would not just ensure Moscow's strong influence in Europe but would also provide Moscow with a stream of endlessly increasing revenue, for it was assumed that gas prices would increase constantly. Recent events, however, have demonstrated shaky ground under Moscow's plans. Europeans have increasingly had access to alternative sources of energy and gas prices have collapsed. In this situation, Moscow has been compelled to make considerable concessions, and the relationship with Bulgaria has demonstrated this.
Recently, Russia has given considerable gas price discounts to Bulgaria. Officially, Moscow announced this as a generous gift to the 'brotherly' Slavic nation in commemoration of the liberation of Bulgaria from the Ottoman Empire after the Russo-Turkish War, almost 150 years ago. However, the true reason for the concession was quite different and pragmatic. Russia has experienced increasing problems in sending gas to European markets; as Bulgaria's market is also included, it will most likely experience even more problems in the future, when alternative gas lines are fully in use. More generally, the Bulgarian deal indicates serious problems in Vladimir Putin's geopolitical arrangements as they pertain to gas and oil.

\section{Bulgaria and Russian Gas}

Bulgaria has depended on its supply of Russian gas for a long time. "Bulgaria imports about 2.4 billion cubic meters (bcm) of gas annually from Gazprom, and 95 percent of its gas needs come from Russian gas imports." 3 It has seemed unlikely that Bulgaria would be able to replace much of the Russian gas in the future. Bulgaria has a contract with Russia which stipulates that Bulgaria shall buy at least 80 percent of its gas from Gazprom until 2022. Still, Sofia has not been pleased in its relationship with Gazprom. Price has been a major sticking point and, since 2019, Bulgaria has demanded a reduction in the price of Russian gas. ${ }^{5}$ By spring 2020, Bulgaria achieved its goal, and the Bulgarian Prime Minister Boyko Borisov stated that the 
40 percent reduction in the price of Russian gas is a symbolic gift to Bulgarians to commemorate the anniversary of Bulgaria's liberation from Ottoman rule. ${ }^{6}$ Some observers had believed that after the new agreement with Russia, Bulgaria would receive the cheapest gas in Europe. ${ }^{7}$ However, after the price reduction, Bulgaria will pay the same price that the rest of Europe pays. ${ }^{8}$

What was the reason for Moscow's concession? One might assume that the reason was Sofia's concessions. In 2018, the European Commission concluded that Gazprom had overcharged many of its East European customers, and that they could demand compensation. Indeed, Poland charged Gazprom with overcharging, and demanded that it return $\$ 1.5$ billion to Poland. Moreover, the shareholders of YukosOil Company had actually been expropriated by the Kremlin at the beginning of $\mathrm{Pu}$ tin's tenure, and demanded several dozen billion dollars in damages. Sofia did not follow this path, and did not ask for compensation. Gazprom would have transmitted gas through the Trans-Balkan Pipeline. Instead, Gazprom bypassed the Trans-Balkan Pipeline and decided to replace it with TurkStream. Again, Sofia did not ask for compensation. Thus, not only Moscow but Sofia had made concessions, and this was the reason for Gazprom's concessions. While Sofia's concessions played some role in Gazprom's move, the most important reason was different. Gazprom experienced serious pressure, the most important form being the emergence of

\section{The Bulgarian Prime Minister Boyko Borisov stated that the $\mathbf{4 0}$ percent reduction in the price of Russian gas is a symbolic gift to Bulgarians to commemorate the anniversary of Bulgaria's liberation from Ottoman rule}

alternative gas lines and the collapse of gas prices, although the EU's pressure might also be taken into account.

\section{The Role of the EU}

Some observers believed that Bulgaria's ability to reduce the price for Russian gas was only due to pressure from the European Union. ${ }^{9}$ EU officials assumed that Gazprom had abused its monopolist position in dealing with the Baltic states and Poland. And in 2018, Gazprom had appeased the EU with certain concessions to these states. ${ }^{10}$

It became clear from the Commission's report that seven of the eight countries under the anti-trust probe had already received a reduction in their supply prices from Gazprom. Bulgaria was the only exception. ${ }^{11}$

Sofia clearly sees that Gazprom can be bent, and that Bulgaria was discriminated against. Consequently, Sofia decided to use the power of EU bureau- 


\section{While EU pressure definitely} played some role in pushing Moscow to engage in price concessions, there were other, possibly even more important reasons for Gazprom's

\section{concessions}

the importance of Bulgaria for the second string of TurkStream. ${ }^{13}$ However, the real picture is more complicated. There were not two, but several reasons. One of them was the general collapse of gas prices, which was a global phenomenon even before the current economic problems. The energy sector has collapsed, ${ }^{14}$ and the price of gas is still falling. ${ }^{15}$

Even before the present-day economic meltdown, Europe did not need much gas. Still, according to the contract, Gazprom continued to send gas via Ukraine. ${ }^{16}$ When gas prices fell and demand shrank, even before the present-day economic turmoil, Russia was hit hard, possibly more than any other gas-producing country. "It should be borne in mind that Gazprom's share in the European market had already been declining due to the fact that the EU tripled the import of liquefied natural gas, including from the United States. Since 2012, the share of Russian gas in the European market has decreased from 34.7 percent to 32 percent." ${ }^{\prime 7}$

Besides general problems with the gas and oil industry, there were other problems that directly affected Gazprom. One of them was the disappointment with TurkStream. Russia's hopes that Turkey would be a vast market for Russian gas did not materialize.

\section{The Collapse of Gas Prices}

Some observers believe that Gazprom reduced prices for Bulgaria for two basic reasons: first, the collapse of gas prices in Europe and second,

\section{The Problem with TurkStream}

In addition to Nord Stream II, Gazprom has developed the TurkStream 


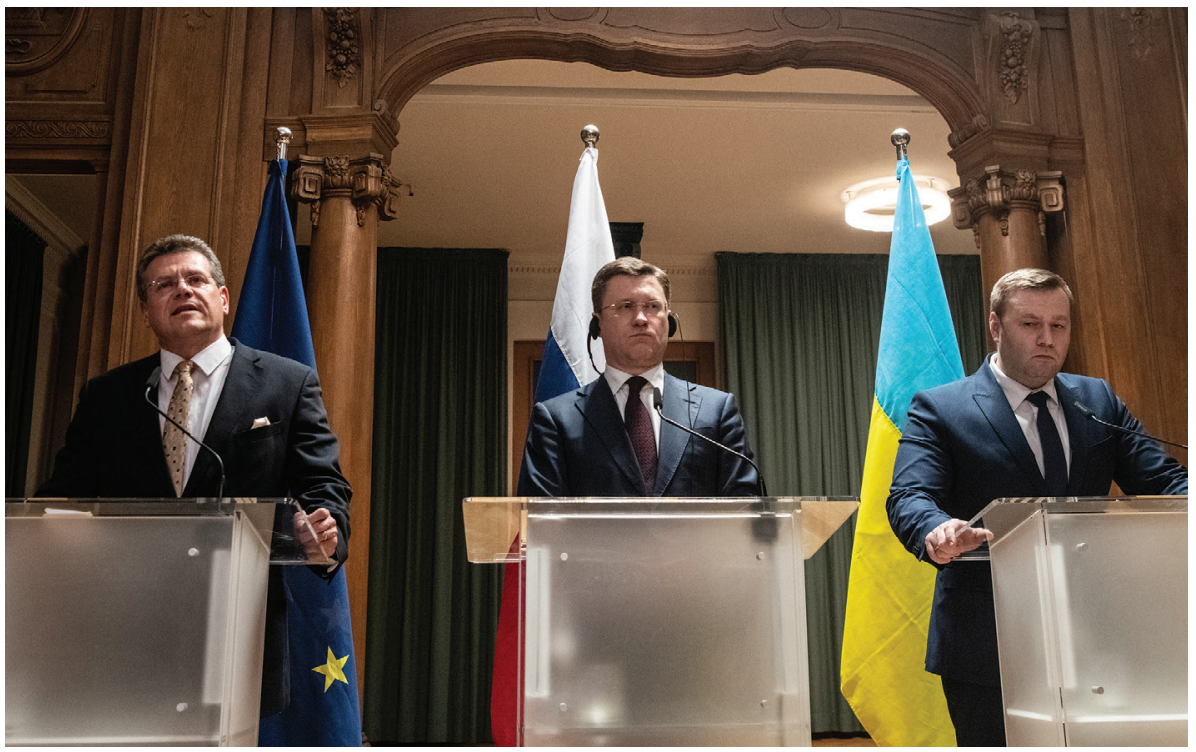

Šefčovič, Vice

President of the EU

Commission, Nowak,

Energy Minister of

Russia, and Orschel,

Energy Minister of

Ukraine, hold a joint

a press conference

after negotiations

between Russia and

Ukraine, following

their agreement in

principle on a new

gas transit contract,

December 19, 2019.

PAUL ZINKEN /

picture alliance via

Getty Images

gas pipeline project with two strings with a capacity of $31.5 \mathrm{bcm}$ of gas per year as an alternative to South Stream. ${ }^{18}$ The Kremlin believed that the U.S. had a limited capacity to stop both Nord Stream II and South Stream II. People in the Kremlin assumed that even if Washington delayed the construction of theses pipelines, it could not stop them from being built, or even more so, prevent the consumption of gas. Indeed, one observer noted that if the U.S. were to impose sanctions against companies in Europe that consume gas from Nord Stream and TurkStream, it would be an act of war against Europe. ${ }^{19}$

Not only Europe but Turkey had emerged as quite an important market for Russian gas. Until very recently, it looked as if Moscow had achieved success at least in building the first string of TurkStream and opening the door to the lucrative Turkish market. The official opening of the first string took place in early January 2020. A news report read: "Russia officially opened its TurkStream natural gas pipeline on Wednesday, further diversifying export routes to Europe amid a backlash from the U.S. President Vladimir Putin and his Turkish counterpart Recep Tayyip Erdogan met in Istanbul to inaugurate the pipeline in a ceremony celebrating the nations' energy and political ties." 20

Yet, Moscow's triumph was shortlived, for Ankara had apparently started to lose interest in Russian gas. Indeed, one observer noted, for a long time, Turkey had been one of the most important consumers of Russian gas in the world. In 2019, however, Turkey's consumption of Russian gas declined sharply. ${ }^{21}$ Reducing the import of the Russian gas 


\section{While LNG has diminished} Bulgarian dependence on Russian gas, the major threat for Gazprom's Bulgaria project comes from several gas pipelines, such as TAP and TANAP
LNG has become cheaper than Gazprom' gas. ${ }^{26}$ Bulgaria plans to receive LNG from different sources; the U.S. is one of them. Indeed, Sofia has developed its relationship with Washington and has purchased U.S. weapons. ${ }^{27}$ Purchasing U.S. weapons goes along with the purchase of U.S. gas, and in spring 2019, Bulgaria started to buy U.S. LNG. ${ }^{28}$ Purchase of U.S. gas was Bulgaria’s first step toward diversifying supplies and reducing dependence on Russian natural gas." ${ }^{29}$

The U.S. was not Bulgaria's only source of LNG, however. Sofia also believed that it could get LNG via Greece. ${ }^{30}$ Consequently, Bulgaria engaged in building an LNG terminal in Greece ${ }^{31}$ and made a considerable investment in the project, ${ }^{32}$ which is currently under construction and will be finished by 2022. Construction of the Gas Interconnector Greece-Bulgaria Project (IGB), which is expected to be finished by $2021,{ }^{33}$ will also provide Bulgaria with LNG $^{34}$ from many countries including the U.S., Qatar, Cyprus, Egypt, and Azerbaijan..$^{35}$ The project was conceived 10 years ago and it would make it possible for Azerbaijani gas to reach Bulgaria. ${ }^{36}$ While LNG has diminished Bulgarian dependence on Russian gas, the major threat for Gazprom's Bulgaria project comes from several gas pipelines, such as Trans Adriatic Pipeline (TAP) and TANAP. ${ }^{37}$ Some of these pipelines are already operational, and some are being built. Among others, Azerbaijan has emerged as a major resource base for Bulgaria. 


\section{Azerbaijani Gas for Europe}

Azerbaijan has been engaged in projects that would deliver gas to Europe for a long time. In 2011, the EU and Azerbaijan signed a declaration that stipulated the creation of a Southern Gas Corridor. In 2012, the Austrian company OMV and Turkish company BOTAŞ proposed "Caspian countries to build 3,300-kilometer-long gas line from Western Turkmenistan through the Caspian Sea, Caucasus, Turkey and Europe to Austrian Baumgarten, the very heart of gas distribution hub, for 32 billion cubic meters of gas." It was called Nabucco. ${ }^{38}$ Turkmenistan was to be the major source of gas for the project. Yet, the project faced Russian resistance, and was finally canceled. Later on, Azerbaijan proposed a shorter version of Nabucco. In this case, the pipeline would use just gas from Azerbaijan. ${ }^{39}$

Although the Nabucco project did not materialize in either form, Azerbaijan has continued its drive to access the lucrative European market. Two pipeline projects emerge here as crucially important for Azerbaijan to achieve its goals: TAP and TANAP. Bulgaria could receive gas from both of them.

\section{TAP}

The TAP was seen as a major way of delivering Azerbaijani gas into Europe, via Greece, Albania, and Italy. ${ }^{40}$ Bulgaria expects to receive a considerable amount of gas from TAP. Indeed, Bulgaria could get up to 1 billion cubic kilometers of gas from Azerbaijan by fall 2020 through TAP and IGB. ${ }^{41}$ While some reports had announced that TAP was already in construction by early fall 2019 , construction was actually launched several months later, in January 2020. ${ }^{42}$

Construction seemed to proceed smoothly, and in February 2020 the Azerbaijani company SOCAR declared that TAP would be operable by the end of 2020. IGB will also be functional by that time. ${ }^{43}$ Sofia has been regarding the project as being quite important, ${ }^{44}$ and intending to build infrastructure in order to benefit from the project. $^{45}$

\section{TANAP}

TANAP is part of the Southern Gas Corridor, along with TAP its major source is Azerbaijan's Shah Deniz II gas field. ${ }^{46}$ The plans to include Turkmenistan's resources do not seem likely at present. ${ }^{47}$

In November 2019, the Turkish President Recep Tayyip Erdoğan and Azerbaijani President Ilham Aliyev inaugurated the European link of TANAP, which "connected Turkey with Europe." ${ }^{48}$ TANAP has become quite important for Bulgaria and required a certain geopolitical adjustment, as it affects Bulgaria's relationship with Armenia. Bulgarian Minister of Foreign Affairs Ekaterina Zaharieva noted in her conversation with Armenian colleagues that Bulgaria values very much its good relationship with Armenia. Still, she noted, Bulgaria needs Azerbaijani gas. ${ }^{49}$ With two major pipelines under construction or operating at partial capacity, Azerbaijan already 


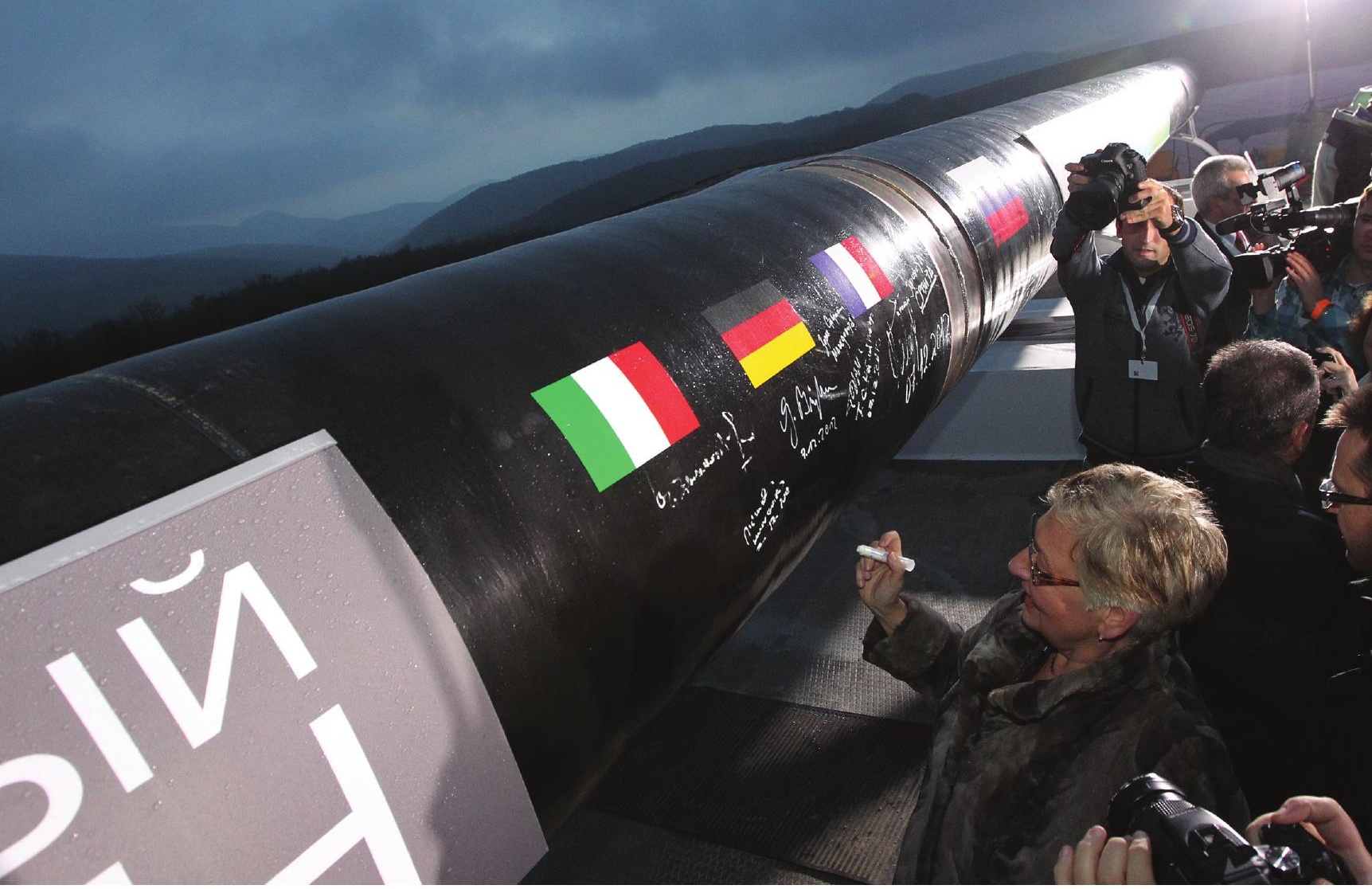

The construction site of the South

Stream, a proposed pipeline project to transport Russian natural gas through the Black Sea to Bulgaria, Greece, Italy, and Austria, December

7, 2012.

SASHA MORDOVETS / Getty Images has a strong foothold on European markets, and is competing well with Gazprom, selling gas in the external markets of several Eastern European countries. $^{50}$ This gave Sofia opportunity to reduce its dependence on Russian gas. At the same time, Sofia felt strong pressure from Washington, if not to abandon TurkStream completely, to at least slow down its construction, and Sofia gave in to this pressure.

\section{Bulgaria and Russian Gas}

Moscow has long regarded Bulgaria as an important link for transferring gas to Europe. In 2007, Gazprom signed an agreement to build South
Stream from Russia to Bulgaria. As the EU blocked the construction, Russia had to abandon the project by $2014 .^{51}$ Later, however, Bulgaria agreed to participate in TurkStream, which was to be, in many ways, a replica of the abandoned Southern Stream and go through Bulgaria, Serbia, and Hungary to Austria. ${ }^{52}$

In Bulgaria, TurkStream was called "Balkan Stream," "possibly to downplay Turkey's importance in the project." ${ }^{33}$ While originally embracing the project and seemingly anxious to finish it as soon as possible, Sofia later started to send contradictory signals. By September 2019, Sofia indicated that it could well totally abandon its participation in the proj- 
ect. Bulgarian ambivalence toward the project went along with general uneasiness in Russian-Bulgarian relations. Indeed, Bulgaria's approach to Russia is contradictory. Sofia makes both pro-Russian and anti-Russian statements. ${ }^{54}$

The problem with TurkStream crossing Bulgaria clearly emerged by March 2019. Most likely responding to Moscow's impatience, Sofia found convenient explanations for the delay; one of them was that Bulgaria had not yet received the EU's blessing for building the second string of TurkStream through its territory. ${ }^{55}$ While the absence of Brussels' blessing was a convenient excuse, some Russian observers claimed that it was not the only reason or possibly not a reason at all. They rather believed that Sofia had second thoughts about the project in general, and it might even abandon it altogether. ${ }^{56}$

This news was hardly pleasing to Moscow. Bulgaria's reluctance, or at least procrastination, in engagement in the project went along with other news, quite negative for Gazprom. There was evidently a decline in interest in Russian gas in Europe. Consequently, Moscow came to the conclusion that Russia could well decide not to build a second string for TurkStream because of competition. ${ }^{57}$

However, by December 2019, Sofia seemed to be sending encouraging signals. According to reports from Sofia, Energy Minister Temenuzhka Petkova said that Bulgaria would "start receiving natural gas from Rus-
Russia has experienced increasing problems in sending gas to European markets; as Bulgaria's market is also included, it will most likely experience even more problems in the future, when alternative gas lines are fully in use

sia's Gazprom via Turkey from January 1 and would no longer use the route through Ukraine and Romania." From Bulgaria the gas would go to Serbia and Hungary. ${ }^{58}$ Yet, simultaneously, Sofia sent an opposite signal, implying that Bulgaria either was not very interested in the project, or would delay it, possibly indefinitely. Bulgarian authorities stated in early December 2019 that they would not be able to complete the construction of its part of TurkStream earlier than the end of 2020. This was a blow to Moscow, which planned to use TurkStream instead of Ukrainian pipelines. ${ }^{59}$ In early December 2019, Turkish President Erdoğan stated that TurkStream would start operating on January 8. But, due to Bulgaria's procrastination, the second string of the pipeline, which would deliver Russian gas in Austria through Bulgaria, Serbia, and Hungary, would remain unfinished. ${ }^{60}$

The very fact that Bulgaria delayed the construction of TurkStream com- 


\section{Under these circumstances,} Sofia has demonstrated its willingness to respond to Washington's pressure and delay the construction of the second string of TurkStream gas, ${ }^{66}$ and has thus resisted U.S. pressure to abandon the project. ${ }^{67}$ Serbia has demanded that TurkStream be built through Bulgaria to Serbia, ${ }^{68}$ and hoped that Bulgaria would finally build TurkStream through its territory, ${ }^{69}$ despite the delay. Still, one could doubt that Belgrade has much influence on Sofia.

\section{Conclusion}

pelled Russia to renew its agreement with Ukraine, which it had tried to avoid by all means possible. ${ }^{61}$ It was not surprising that the Kremlin was outraged: "The Russian president stressed that if the Bulgarian authorities do not want to participate in the project and if the situation repeats itself as with the South Stream gas pipeline project, then another route will be found for the transit of Russian natural gas." ${ }^{2}$ Despite the Kremlin's warnings and threats, Bulgaria continued to delay construction. ${ }^{63}$ Additional problems also emerged. In January 2020, Bulgaria announced that it was going to replace half of its imports of Russian gas. There were also tensions between Moscow and Sofia due to spy scandals. ${ }^{64}$

The increasing tension between Moscow and Sofia affected gas supply to nearby Turkey. Turkey complained that it could not get gas from Bulgaria because the pipelines were still controlled by Gazprom. ${ }^{65}$ The delay also frustrated Serbia, which demanded that Bulgaria finish TurkStream on Bulgarian territory. Serbia badly needs TurkStream, for it has no other alternative sources for natural
Gazprom's desire to drastically reduce prices for Bulgaria has nothing to do with either abstract benevolence or supposedly historical ties between two 'brotherly' Slavic peoples. Even pressure from the EU might not be the most important factor in Gazprom's decision-making. Russia's reduction of gas prices was primarily due to increasingly unfavorable conditions for Gazprom's operations in Europe in general, and Bulgaria in particular. There, the price of gas has fallen, and new alternatives to Russian gas, such as LNG and Azerbaijani gas, have emerged. Under these circumstances, Sofia has demonstrated its willingness to respond to Washington's pressure and delay the construction of the second string of TurkStream. With this delay, Sofia signaled to Moscow that it would continue with the construction only if it received a considerable discount. The Kremlin relented in the face of this pressure.

What are the implications of the Kremlin's conundrum? For a long time, the Kremlin assumed that gas pipelines would not only ensure a 
steady and even increasing flow of cash, but also help to increase Russia's influence in Europe. The Bulgaria debacle has demonstrated the limits of Moscow's project. Of course, one can ask who would benefit most from the new arrangements. One might assume that it could be the U.S.. Indeed, President Donald Trump has put much hope in LNG which, in his plans, will put an end to the deficit and restore the U.S.' general economic predominance. As in the case with Putin's plans, however, Trump's plans are also basically a pipe dream. There is no way that raw material exports, which is usually associated with thirdworld countries, can ensure economic and geopolitical dominance in the present-day world. It is therefore most likely that China would be the greatest beneficiary of falling gas prices and Russia's problems in selling gas to Europe. Indeed, China is increasingly becoming a major market for Russian gas, and Gazprom is already planning the second string of the Power of Siberia pipeline.

\section{Endnotes}

1. Janusz Bugajski, "Regional Overview," in Western Balkans Policy Review 2010, Center for Strategic \& International Studies, (September 2010), p. 8.

2. See, for example, Aleksandar Kovačevic, "Towards a Balkan Gas Hub: The Interplay Between Pipeline Gas, LNG, and Renewable Energy in South East Europe," Oxford Institute for Energy Studies, (2017), retrieved from https://www.oxfordenergy. org/publications/30072/; Ognian Shentov, Ruslau Stefanov and Martin Vladimirov, (eds.), The Russian Economic Grip on Central and Eastern Europe, (New York: Routledge, 2019); Lukâš Tichy, EU-Russia Energy Relations, (Springer, 2019).

3. Shokri Halensar, "Azerbaijan's Role in EU Energy Security: The Geopolitics of the SGC," Daily Sa- bah, (November 22, 2019), retrieved from https:// www.dailysabah.com/op-ed/2019/11/22/azerbaijans-role-in-eu-energy-security-the-geopolitics-of-the-sgc.

4. Igor Fedik, "Kak Izbavit'sia ot "Gazproma». Plamen Dimitrov pro Novuiu Gazovuiu Ėpokhu v Bolgarii," Glavkom, (March 1, 2020), retrieved from https://glavcom.ua/ru/interview/kak-izbavitsyaot-gazproma-plamen-dimitrov-pro-novuyu-gazovuyu-epohu-v-bolgarii-662711.html.

5. "Telefonnyı̆ Razgovor Putina i Radeva Usilil Raskol v Rukovodstve Bolgarii," Regnum, (February 19, 2020), retrieved from https://regnum. ru/news/polit/2863240.html; "Bolgariia Vsled za Belorussiel Zaprosila u Gazproma Skidku na Gaz," Rusevik.ru, (February 11, 2020), retrieved from https://rusevik.ru/news/584254.

6. Gennadiĭ Gabrièlian, "Rossiia na $40 \%$ Snizila Tsenu na Gaz dîa Bolgarii," Novaia Gazeta, (March $4,2020)$, retrieved from https://novayagazeta.ru/ news/2020/03/04/159515-rossiya-na-40-snizilatseny-na-gaz-dlya-bolgarii; "Gazprom Agrees to $40 \%$ Cut on Gas Price to Bulgaria," Kallanish Energy, (March 4, 2020), retrieved from https://www. kallanishenergy.com/2020/03/04/gazpromagrees-to-40-cut-on-gas-price-to-bulgaria/; '"Gazprom' ne Mozhet Diktovat' Usloviia ES: Rezko Snizhena Tsena Gaza dlia Bolgarii," DW, (March 4, 2020), retrieved from https://www.dw.com/ ru/газпром-не-может-диктовать-условия-есрезко-снижена-цена-газа-для-болгарии-dwновости-04032020/av-52641842.

7. "«Gazprom» Zablokiroval Turtsiiu ot Deshevogo Rossiǐskogo Gaza iz Bolgarii," EurAsia Daily, (March 4, 2020), retrieved from https://eadaily. com/ru/news/2020/03/04/gazprom-zablokiroval-turciyu-ot-deshevogo-rossiyskogo-gaza-izbolgarii.

8. Igor' IUshkov, "Pochemu «Gazprom» dal Skidku na Gaz dlia Bolgarii," RNS, (March 3, 2020), retrieved from https://rns.online/opinions/Pochemu-Gazprom-dal-skidku-na-gaz-dlya-Bolgarii2020-03-03/.

9. Fedik, "Kak Izbavit'sia ot "Gazproma». Plamen Dimitrov pro Novuiu Gazovuiu Ėpokhu v Bolgarii."

10. ''Gazprom' Snizil Tsenu na Gaz dlia Bolgarii na 40\%," Kommersant, (March 8, 2020), retrieved from https://www.kommersant.ru/doc/4275788.

11. Georgi Gotev, "Bulgaria Mulls Re-opening Gazprom Antitrust Probe," Euractiv.com, (March 2, 2020), retrieved from https://www.euractiv.com/ section/competition/news/bulgaria-mulls-reopening-of-the-gazprom-probe/. 
12. Fedik, "Kak Izbavit'sía ot «Gazproma». Plamen Dimitrov pro Novuiu Gazovuiu Ėpokhu v Bolgarii."

13. Ol'ga Samofalova, "TŚenovaia Voĭna v Evrope zastavliaet Gazprom Idti na Ser'eznye Ustupki," Vzgliad, (March 4, 2020), retrieved from https://vz.ru/economy/2020/3/4/1026928.html.

14. Andrea Riquier, "'We Are Giving Up on Energy,' Say Jefferies Analysts, Who Go On to Compare the Beaten-down Sector to the '62 Mets" Market Watch, (March 9, 2020), retrieved from https:// www.marketwatch.com/story/we-are-giving-upon-energy-says-jefferies-analysts-who-compares-beaten-down-sector-with-62-mets-202003-04.

15. “Kak Bolgariia Ubila Poslednii Shans Moskvy vBol'shoi Voine - Reshaiushchaia Bitva uzhe Proigrana," Dialog.ua, (December 5, 2019), retrieved from https://www.dialog.ua/business/196096_15 75569166.

16. "Temnye Bremena Gazproma: Evrope ne Huzhen Dazhe Deshevyı̆ Gaz," Novye Izvestiiia, (March $3,2020)$, retrieved from https://newizv.ru/article/ general/03-03-2020/temnye-vremena-gazproma-evrope-ne-nuzhen-dazhe-deshevyy-gaz.

17. Georgiy Kuhaleyshvili, "Russian-Bulgarian Crisis: Meaning of the Borisov and Trump Gas Games," 112.ua, (December 11, 2019), retrieved from https://112.international/politics/russianbulgarian-crisis-meaning-of-borisov-and-trumpgas-games-46459.html.

18. Kuhaleyshvili, "Russian-Bulgarian Crisis."

19. Fedik, "Kak Izbavit'sia ot «Gazproma». Plamen Dimitrov pro Novuiu Gazovuiu Ėpokhu v Bolgarii."

20. Olga Tanas, "Russia Readies New Gas Link to Europe in Defiance of U.S," Bloomberg Quint, (January 8, 2020), retrieved from https://www. bloombergquint.com/business/russia-opensnatural-gas-link-to-turkey-amid-u-s-opposition.

21. Aleksandr SHustov, "Azerbaĭdzhanskil Gaz Obkhodit Rossiiu CHerez Turtsiiu," Ritm Evrazii, (February 23, 2020), retrieved from https:// www.ritmeurasia.org/news--2020-02-23--azerbajdzhanskij-gaz-obhodit-rossiju-cherez-turciju-47644.

22. Kuhaleyshvili,"Russian-Bulgarian Crisis.”

23. Ekaterina Katkova, "Bespoleznaia Truba? iz "Turetskogo Potoka» Ukhodit Gaz," Gazeta.ru, (May 14, 2019), https://www.gazeta.ru/business/ 2019/05/14/12354361.shtml.

24. Dmitriĭ Rodionov, Alekseĭ Il'iashevich and Igor' IUshkov, “Otvetit li Papasha Miller za Grandio- znye Provaly Rossiīskoĭ "gazovoĭ imperii"?," TSentrAziia, (February 18, 2020), retrieved from https:// centrasia.org/newsA.php?st=1582048020.

25. "Rossii Grozit Arest Aktivov Posle Resheniiia Suda Gaagi po Delu "IÚkosa",' Novosti oilru.com, (February 19, 2020), retrieved from https://www. oilru.com/news/562665/.

26. Fedik, "Kak Izbavit'sia ot «Gazproma». Plamen Dimitrov pro Novuiu Gazovuiu Ėpokhu v Bolgarii."

27. Kuhaleyshvili, "Russian-Bulgarian Crisis."

28. "Bulgaria in First U.S. Gas Deals Buys Two LNG Cargoes," Reuters, (May 31, 2019), retrieved from https://www.reuters.com/article/bulgaria-Ingusa/bulgaria-in-first-us-gas-deals-buys-two-Ingcargoes-idUSL8N2371VV.

29. "First American Liquefied Gas for Bulgaria," novinits.com, (March 6, 2020), retrieved from https:// www.novinite.com/articles/197555/First+American+Liquefied+Gas+for+Bulgaria.

30. "'Gazprom' Snizil Tsenu na Gaz dlia Bolgarii na 40\%."

31. "Bolgariia Potratit Den'gi ot Rossiǐskogo Gaza na Plavuchii SPG-Terminal," News Front, (January 13, 2020), retrieved from https://news-front.info/ 2020/01/13/bolgariya-potratit-dengi-ot-rossijskogo-gaza-na-plavuchij-spg-terminal/.

32. SHustov, "Azerbaĭdzhanskiĭ Gaz Obkhodit Rossiiu CHerez Turtsiiu."

33. Fedik, "Kak Izbavit'sia ot «Gazproma». Plamen Dimitrov pro Novuiu Gazovuiu Ėpokhu v Bolgarii."

34. Svetoslav Todonov, "Bulgaria Buys Share of Greek Gas Terminal," Balkan Insight, (January 10, 2020), retrieved from https://balkaninsight.com/ 2020/01/10/bulgaria-takes-role-in-greek-gasterminal/; "Greece, Bulgaria Pledge to Accelerate IGB's Construction in Tandem with TAP," News.az, (February 27, 2020), retrieved from https://www. azernews.az/region/162281.html.

35. "Bolgariia Poluchit Nezavisimost' ot «Gazproma» v 2020 Godu - Boľko Borisov," Realist, (March 6, 2020), retrieved from http://realtribune. ru/news/news/3098; "Bolgariia Ozhidaet Azerbaĭdzhanskiĭ Gaz po IGB v 2020g - Prem'er-Ministr," Interfaks-Azerbaìdzhan, (November 12, 2019), retrieved from https://interfax.az/view/783688; E. Alifirova, "Bolgariia Voshla v Proekt Stroitel'stva SPG-terminala v Gretsii i Ozhidaet Skidok na SPG ot SSHA," Neftegaz.ru, (January 10, 2020), retrieved from https://neftegaz.ru/news/ transport-and-storage/517052-bolgariya-voshla-v-proekt-stroitelstva-terminala-spg-v-gretsii/. 
36. Fedik, "Kak Izbavit'sia ot "Gazproma». Plamen Dimitrov pro Novuiu Gazovuiü Ėpokhu v Bolgarii."

37. SHustov, "Azerbaĭdzhanskiĭ Gaz Obkhodit Rossiiu CHerez Turtsiiu."

38. Igor' Ivakhnenko, "Turetskiĭ Gambit, CHast' Vtoraia," Oilcapital.ru, (February 3, 2020), retrieved from https://oilcapital.ru/article/general/04-02-2020/turetskiy-gambit-chast-vtoraya.

39. Ivakhnenko, "Turetskiĭ Gambit, CHast' Vtoraia."

40. "Turkey and Azerbaijan Mark Completion of TANAP Pipeline to Take Gas to Europe," Reuters, (November 30, 2019), retrieved from https://www. reuters.com/article/us-turkey-energy-tanap/turkey-and-azerbaijan-mark-completion-of-tanappipeline-to-take-gas-to-europe-idUSKBN1Y40CP.

41. "Turkey and Azerbaijan Mark Completion of TANAP Pipeline to Take Gas to Europe."

42. "Konkurenta «Turetskogo Potoka» Tianut na Dno," EADaily, (January 29, 2020), retrieved from https://eadaily.com/ru/news/2020/01/29/ konkurenta-tureckogo-potoka-tyanut-na-dno.

43. N. Abbasova, "SOCAR: Kraĭniĭ Crok Zapuska Gazoprovoda TAP - Konets 2020g," Natsional'naia Assotsiatsiia Heftegazovogo Cervisa, (February 14, 2020), retrieved from https://nangs. org/news/world/dobycha-nefti-v-ssha-k-kontsugoda-mozhet-upasty-na-28-mln-bs-v-srednempo-godu-na-11-mln-bs-v-sravnenii-s-2019g-mea.

44. "Bolgariia Poluchit Nezavisimost' ot «Gazproma» v 2020 Godu - Bolko Borisov."

45. Fedik, "Kak Izbavit'sia ot "Gazproma». Plamen Dimitrov pro Novuiu Gazovuiu Ėpokhu v Bolgarii."

46. Abbasova, "SOCAR: Kraĭniĭ Crok Zapuska Gazoprovoda TAP - Konets 2020g."

47. Liudmila Podobedova and Anzhelika Basisini, "Ugroza iz Baku: Naskol'ko Opasen Novyı̆ Gazoprovod dlia "Gazproma»," RBC.ru, (May 29, 2018), retrieved from https://www.rbc.ru/business/29/05/2018/5b0d2a389a79472bcb56ab94

48. Ivakhnenko, "Turetskiĭ Gambit, CHast' Vtoraia."

49. "Gaz iz Azerbaĭdzhana Nuzhen, no i Armeniia Vazhna - Glava MID Bolgarii v Erevane," Sputnik (Armenia), (October 28, 2019), retrieved from https://ru.armeniasputnik.am/society/20191028/ 20904479/Gaz-iz-Azerbaydzhana-nuzhen-no-iArmeniya-vazhna--glava-MID-Bolgarii-v-Erevane. html.

50. "«Gazpromu» i ne Snilos': Baku Zanimaet Svobodnye Nishi v Prichernomor'e," EADaily, (Febru- ary 1, 2019), retrieved from https://eadaily.com/ ru/news/2019/02/01/gazpromu-i-ne-snilos-baku-zanimaet-svobodnye-nishi-v-prichernomore.

51. Kuhaleyshvili, "Russian-Bulgarian Crisis."

52. Ivakhnenko, "Turetskiĭ Gambit, CHast' Vtoraia."

53. Todorov, "Bulgaria Buys Share of Greek Gas Terminal."

54. Ivan Abakumov, "RossiǐskiĬ gaz v Obkhod Ukrainy Poĭdet cherez Bolgariiu," Vzgliad, (September 18, 2019), retrieved from https://vz.ru/ world/2019/9/18/998467.html.

55. Anastasiia Bashkatova, "Bolgariia Pugaet Rossiiu Gazovym Iskom," Nezavisimaia Gazeta, (March 12, 2019), retrieved from https://www.ng. ru/economics/2019-03-12/1_7528_claim.html.

56. "Kak Bolgariia i ES Pomogaiut Ukraine Sokhranit'oTranzit Rossiǐskogo Gaza," Tsargrad, (September 12, 2019), https://tsargrad.tv/articles/ kak-bolgarija-i-es-pomogajut-ukraine-sohranittranzit-rossijskogo-gaza_216638.

57. G. Vlaovic, "Danas (Serbiia): Novyĭ Azerbaĭdzhanskiĭ Gazoprovod Serbii ne Pomozhet," Inocimi.ru, (September 16, 2019), retrieved from https://inosmi.ru/politic/20190916/245832417. html.

58. "Bulgaria to Get Russian Gas Supplies via TurkStream," Reuters, (December 29, 2019), retrieved from https://www.reuters.com/article/bulgariarussia-gas-idAFL8N29414X.

59. "Kak Bolgariia Ubila Poslednii Shans Moskvy v Bol'shoi Voine - Reshaiushchaia Bitva uzhe Proigrana;" "Bolgariia Obeshchaet opozdat' s Prodolzheniem "Turetskogo Potoka» na Piat'iMesiatsev," EADaily, (December 13, 2019), retrieved from https://eadaily.com/ru/news/2019/12/13/ bolgariya-obeshchaet-opozdat-s-prodolzheniem-tureckogo-potoka-na-pyat-mesyacev.

60. Kuhaleyshvili, "Russian-Bulgarian Crisis."

61. "Dnevnik (Bolgariia): Kak "IUzhnnyĭ potok» stal «Turetskim»," Inosmi.ru, (January 10, 2020), retrieved from https://inosmi.ru/politic/2020011 0/246584146.html.

62. Kuhaleyshvili, "Russian-Bulgarian Crisis"; Artur Toporkov, "Putin Obvinil Bolgariiu v Sryve Planov «Gazproma»," Vedomosti, (December 4, 2019), retrieved from https://www.vedomosti.ru/business/articles/2019/12/04/817882-turetskii-potok.

63. "Bolgariia Zatormozila «Turetskiĭ Potok»," Lenta.ru, (February 28, 2020), retrieved from https://lenta.ru/news/2020/02/28/bulgar/; 
«Gazprom» Pomozhet Saudovtsam Dostroit" «Turetskil Potok» v Bolgarii," EADaily, (February $28,2020)$, retrieved from https://eadaily.com/ru/ news/2020/02/28/gazprom-pomozhet-saudovcam-dostroit-tureckiy-potok-v-bolgarii.

64. Kseniya Kirillova, "Russia Faces New Demands and Conditions from Bulgaria," Eurasia Daily Monitor, Vol. 17, No. 22, (February 19, 2020), retrieved from https://jamestown.org/program/russia-faces-new-demands-and-conditions-from-bulgaria/; Gennadiǐ Gabriẻlian, "Bolgariía Ob"íavila o Sokrashchenii Vdvoe Postavok Rossiǐskogo Gaza k Kontsu Goda," Novaia Gazeta, (January 28, 2020), retrieved from https://novayagazeta. ru/news/2020/01/28/158618-bolgariya-ob-yavila-o-sokraschenii-vdvoe-postavok-rossiyskogogaza-k-kontsu-goda.

65. "«Gazprom» Zablokiroval Turtsiiu ot Deshevogo Rossiǐskogo Gaza iz Bolgarii."
66. "Serbiia ne Pozvolit Ostanovit' Stroitel'stvo Prodolzheniia "Turetskogo Potoka»," EADaily, (March 6, 2020), retrieved from https://eadaily. com/ru/news/2020/03/06/serbiya-ne-pozvolitostanovit-stroitelstvo-prodolzheniya-tureckogo-potoka.

67. "SSHA Vtikharia Trebuiut ot Serbii Otkazat'sia ot 'Turetskogo Potoka",' Utro.ru, (March 5, 2020), retrieved from https://utro.ru/politics/ 2020/03/05/1437640.shtml.

68. "U «Turetskogo Potoka» Novye Problemy," la Rex, (March 6, 2020), retrieved from https://iarex. ru/news/73949.html.

69. "Srbijagas: Bulgaria Will Pay Big Penalty if it Abandons the TurkStream Project," Novinite.com, (March 4, 2020), retrieved from https://www.novinite.com/articles/203443/Srbijagas\%3A+Bulgaria+will+Pay+Big+Penalty+if+it+Abandons+ the+Turk+Stream+Project. 


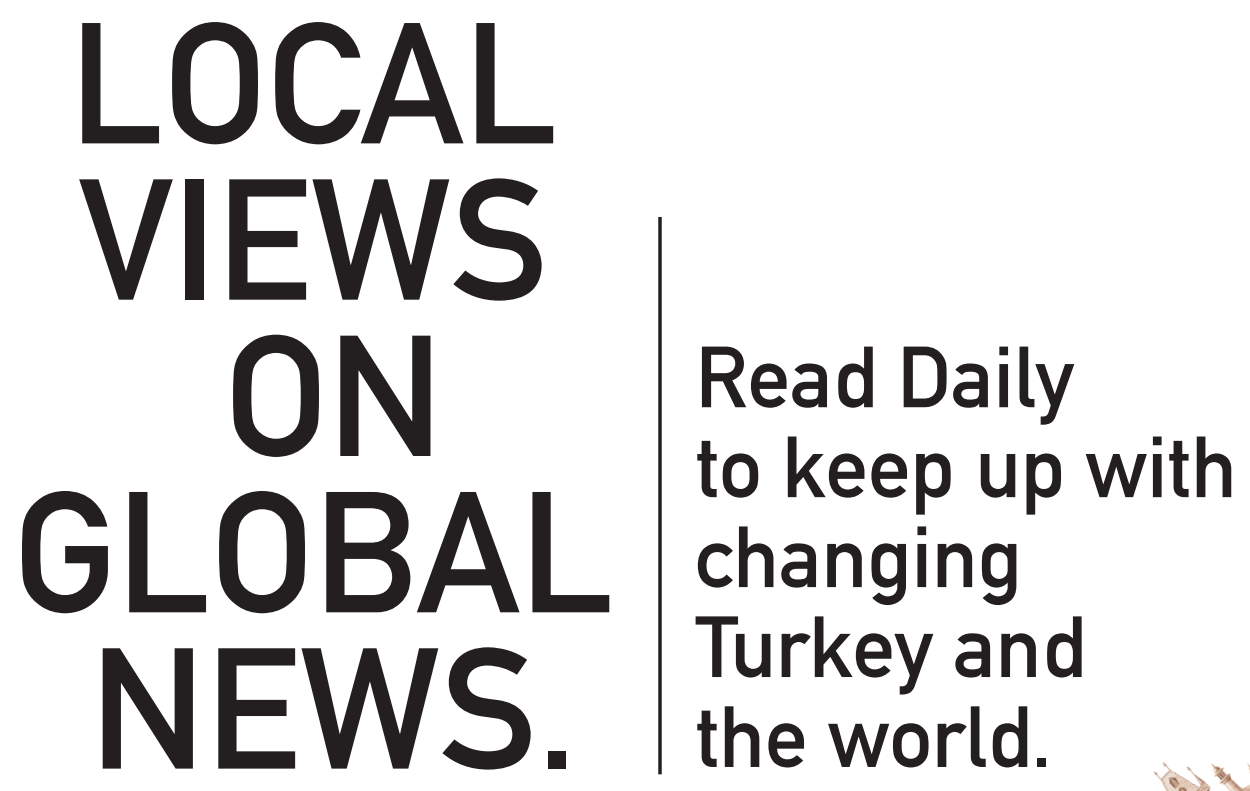

\section{DAILY 马AВAH}

